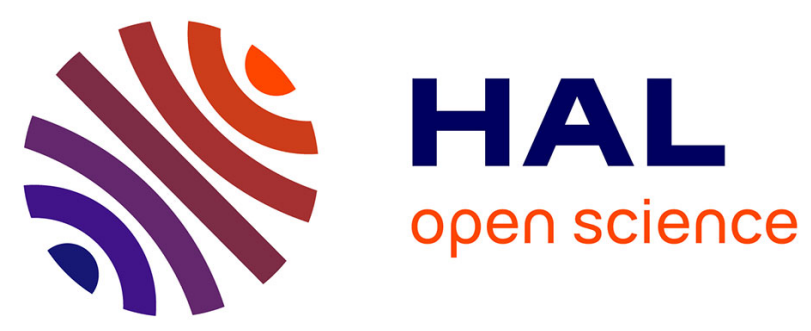

\title{
Tropospheric aerosol ionic composition in the Eastern Mediterranean region
}

N. Mihalopoulos, E. Stephanou, M. Kanakidou, S. Pilitsidis, P. Bousquet

\section{To cite this version:}

N. Mihalopoulos, E. Stephanou, M. Kanakidou, S. Pilitsidis, P. Bousquet. Tropospheric aerosol ionic composition in the Eastern Mediterranean region. Tellus B - Chemical and Physical Meteorology, 1997, 49 (3), pp.314-326. 10.3402/tellusb.v49i3.15970 . hal-03347863

\section{HAL Id: hal-03347863 \\ https://hal.science/hal-03347863}

Submitted on 17 Sep 2021

HAL is a multi-disciplinary open access archive for the deposit and dissemination of scientific research documents, whether they are published or not. The documents may come from teaching and research institutions in France or abroad, or from public or private research centers.
L'archive ouverte pluridisciplinaire HAL, est destinée au dépôt et à la diffusion de documents scientifiques de niveau recherche, publiés ou non, émanant des établissements d'enseignement et de recherche français ou étrangers, des laboratoires publics ou privés. 


\title{
Tropospheric aerosol ionic composition in the Eastern Mediterranean region
}

\author{
By N. MIHALOPOULOS ${ }^{1 *}$, E. STEPHANOU ${ }^{1}$, M. KANAKIDOU ${ }^{2}$, S. PILITSIDIS ${ }^{1}$ and P. \\ BOUSQUET ${ }^{2},{ }^{1}$ Environmental and Analytical Chemistry Division, Department of Chemistry, University \\ of Crete, PO Box 1470, 71409 Heraklion, Greece; ${ }^{2}$ Centre des Faibles Radioactivités, Laboratoire Mixte \\ CNRS/CEA, Orme des Merisiers, Bât 709/LMCE, CE Saclay, 91191 Gif-sur-Yvette Cedex, France
}

(Manuscript received 13 June 1996; in final form 3 March 1997)

\begin{abstract}
Concentrations of the major soluble ions: sulfate $\left(\mathrm{SO}_{4}^{-}\right)$, nitrate $\left(\mathrm{NO}_{3}^{-}\right)$, chloride $\left(\mathrm{Cl}^{-}\right)$, methanesulfonate (MSA), sodium $\left(\mathrm{Na}^{+}\right)$, ammonium $\left(\mathrm{NH}_{4}^{+}\right)$, potassium $\left(\mathrm{K}^{+}\right)$, calcium $\left(\mathrm{Ca}^{++}\right)$and magnesium $\left(\mathrm{Mg}^{++}\right)$, have been measured in 49 aerosol samples collected over a year period at a coastal site of the island of Crete in the Eastern Mediterranean. Significant correlations have been observed between nss- $\mathrm{SO}_{4}^{=}$(non-sea salt sulfate) and $\mathrm{NH}_{4}^{+}$and $\mathrm{Cl}^{-}$and $\mathrm{NO}_{3}^{-}$. The $\mathrm{NH}_{4}^{+} / \mathrm{SO}_{4}^{-}$equivalent ratio was 0.32 . Comparison between total measured concentrations of anions and cations shows a clear deficit of cations. Correlation observed between the cation deficit and the nss- $\mathrm{SO}_{4}^{=}$concentrations suggests that $\mathrm{H}^{+}$is probably the missing cation. Taking into consideration MSA/nss- $\mathrm{SO}_{4}^{=}$ratios, the contribution of biogenic sulfur in the Eastern Mediterranean was evaluated between 0.6 and $28.3 \%$. The variations in the ion concentrations are discussed conjointly with meteorological data and 5-day back trajectories of air masses.
\end{abstract}

\section{Introduction}

During recent years, considerable attention has been paid to the study of the impact of aerosols on human health, reduction of visibility and climatic change. It is now recognised that tropospheric aerosol particles influence the radiative balance of Earth directly and indirectly. Their direct effect is due to the back scattering and absorption of solar shortwave radiation. Their indirect effect on climate is linked to the formation of cloud condensation nuclei (CCN) and consequently to the number of cloud droplets, which enhance shortwave albedo of clouds (IPCC, 1994). Model calculations showed that aerosols (others than black carbon) can carry on a net negative climate forcing (cooling of the atmosphere) which could partly offset the current anthropogenic

\footnotetext{
* Corresponding author. mihalo@hercules.cc.uch.gr
}

greenhouse gas forcing (heating of the atmosphere; IPCC, 1994). According to Charlson et al. (1991) this impact could be higher in regions located downwind the major industrial areas. The Eastern Mediterranean could be characterised as an area of this type. Over this region, Charlson et al. (1991) calculations showed a global maximum of negative radiative forcing due to the presence of $\mathrm{SO}_{4}^{=}$aerosols.

The Mediterranean basin is surrounded at its northern margin with the highly populated (about 100 million inhabitants) areas of South Europe and its southern margin with the northern African continent. The Mediterranean is subject to continuous fluxes of anthropogenic and natural organic and mineral matter. This material is often deposited through riverine but also through atmospheric input. The atmosphere above the Mediterranean is under the influence of air masses originating either from arid regions (Sahara 
desert) or from the polluted areas of North and East Europe. There is strong evidence that atmospheric transport of trace elements from anthropogenic and land-sources to the Mediterranean area, also plays a significant rôle on the geochemistry of its marine environment (Arnold et al., 1982; Bergametti et al., 1989). However, most of the published studies on the input of biogenic and anthropogenic compounds into the Mediterranean sea-water were conducted in its western part (Dulac et al., 1987; Bergametti et al., 1989; Simo et al., 1991; Sicre et al., 1990). For the Eastern Mediterranean area most of the data have been collected at urban centers (i.e. Thessaloniki and Athens, Greece (Tsitouridou and Samara, 1993; Kyrkitsos and Sikiotis, 1991) and Tel-Aviv, Israel (Mamane et al., 1980)), and therefore can not be considered as characteristic of the Eastern Mediterranean atmosphere. There are only very few studies conducted in the background atmosphere and focusing either on fine organic aerosols (Stephanou, 1992; Gogou et al., 1994), or on transport of Sahara dust (Ganor and Mamane, 1982; Mamane et al., 1982). To our knowledge the work presented here is the first attempt to determine the characteristic ionic composition of aerosols in the background atmosphere of the southern part of the Eastern Mediterranean.

We present here the first data on the ionic composition of 49 aerosol samples collected at a coastal rural site in the Eastern Mediterranean area from March 1994 to April 1995. These data in conjunction with air mass back trajectory analysis allow the assessment of the impact of long range transport from various sources on the ionic composition of aerosols in this area. The contribu- tion of the biogenic source to the sulfur budget is also evaluated and discussed.

\section{Experimental}

\subsection{The site}

The sampling station is situated at Finokalia $\left(25^{\circ} 40^{\prime} \mathrm{E}, 35^{\circ} 20^{\circ} \mathrm{N}\right)$ in the northern coast of Crete (Fig. 1). The nearest largest urban centre is Heraklion with 150000 inhabitants located $70 \mathrm{~km}$ west of Finokalia (Fig. 1). The station is located at the top of a hilly elevation $(130 \mathrm{~m})$ facing the sea within a sector of $270^{\circ}$ to $90^{\circ}$. The nearest village with 10 inhabitants is at a distance of $3 \mathrm{~km}$ to the south of the station. No touristic or other type of human activities can be found at a distance shorter than $20 \mathrm{~km}$ within the above mentioned sector.

\subsection{Sampling and analysis of filters}

24-h aerosol samples were collected by using a commercially available Hi-Vol Sierra Andersen sampler housed within an aluminium shelter situated at the top of a $15 \mathrm{~m}$ high tower. The aerosols were collected onto $20 \mathrm{~cm} \times 25 \mathrm{~cm}$ quartz filters. 9 samples were also collected on glass fiber or Whatman-41 filters. Simultaneous sampling performed with quartz and glass fiber filters and with quartz and Whatman-41 filters showed a good agreement (within 15\%) between the results obtained with the different types of filters used (see also subsection 3.4). Before sampling, filters were calcinated (baked at $450^{\circ} \mathrm{C}$ ). The Whatman-41 filters were previously washed with

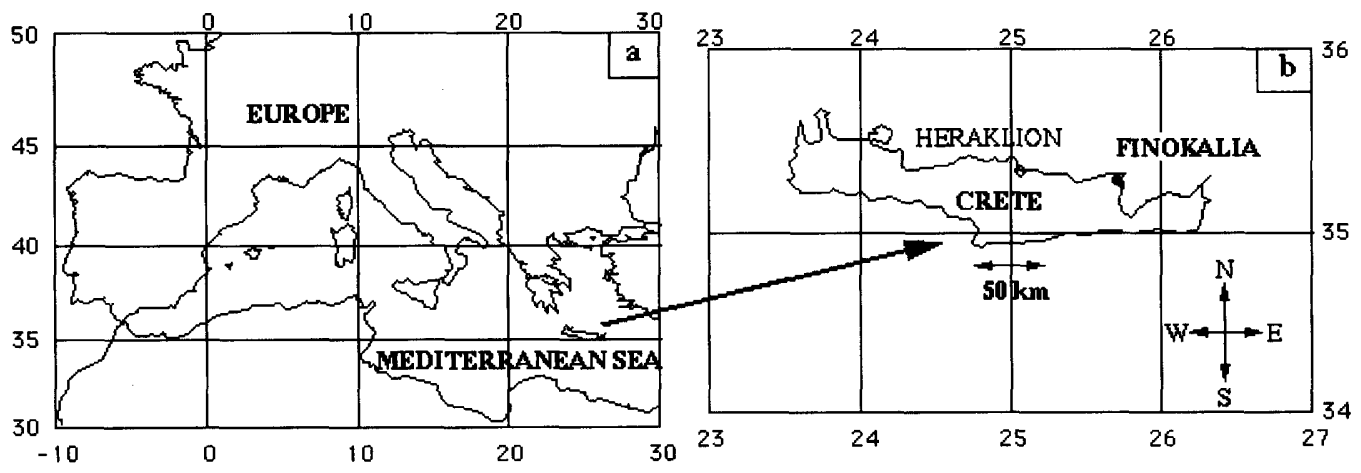

Fig. 1. Maps illustrating the location of Crete (a) and Finokalia (b). 
$\mathrm{HCl} 0.1 \mathrm{~N}$, then cleaned 3 times using ultra pure water until their $\mathrm{pH}$ reached the value of 5.6, typical for the water used. After sampling filters were covered by prewashed and pre-calcinated aluminium foil, sealed in polyethylene bags and stored in a refrigerator at $4{ }^{\circ} \mathrm{C}$ until ion chromatographic analysis. An eighth (1/8) of the total filter was extracted by sonication during $30 \mathrm{~min}$ in $25 \mathrm{ml}$ of ultra-pure water.

After extraction $40 \mu \mathrm{l}$ of $\mathrm{CHCl}_{3}$ were added to the aliquots before their storage at $4^{\circ} \mathrm{C}$ until analysis. An ASA4 Dionex column was used for the analysis of anions (chloride: $\mathrm{Cl}^{-}$, nitrate: $\mathrm{NO}_{3}^{-}$, sulfate: $\mathrm{SO}_{4}^{-}$, methanesulfonate: MSA) and a CS10 Dionex column was used for the analysis of cations (sodium: $\mathrm{Na}^{+}$, ammonium: $\mathrm{NH}_{4}^{+}$, potassium: $\mathrm{K}^{+}$, magnesium: $\mathrm{Mg}^{++}$and calcium: $\mathrm{Ca}^{++}$). The reproducibility of the measurements was better than $2 \%$ and the detection limit corresponded to $2 \mathrm{pmol} / \mathrm{m}^{3}$ of air for a mean volume of $1500 \mathrm{~m}^{3}$. Mean blanks values for MSA, $\mathrm{Cl}^{-}$, $\mathrm{NO}_{3}^{-}, \mathrm{SO}_{4}^{=}, \mathrm{Na}^{+}, \mathrm{NH}_{4}^{+}, \mathrm{K}^{+}, \mathrm{Mg}^{++}$and $\mathrm{Ca}^{++}$ were $<0.08, \quad 250 \quad(100-350), \quad 6.9, \quad 12.2, \quad 500$ $(300-700),<0.08,80,4.8$ and $6.4 \mu \mathrm{g}$, respectively. With exception of $\mathrm{Cl}^{-}$and $\mathrm{Na}^{+}$, the above masses correspond to less than $5 \%$ of the minimum mass of the corresponding ion measured on the analysed filters. For $\mathrm{Cl}^{-}$and $\mathrm{Na}^{+}$this value is $10 \%$ and $20 \%$, respectively.

\subsection{Quality assurance control}

Filter extraction tests as a function of time revealed that the above mentioned procedure allows a recovery of all species of interest of $96 \%$ to $99 \%$. Earlier studies (e.g., Spicer et al., 1982; Appel et al., 1984; Pierson et al., 1976; Lipfert, 1994; Keene et al., 1990) reported artifacts (positive or negative) during sampling. The positive artifacts result from the conversion from gaseous to particulate forms of pollutants passing through the filter, due to the nature of filter medium (especially $\mathrm{pH}$ ) and/or reactions with collected particles. The negative ones result from loss of material during collection. After several tests, we conclude that our filter-samples were not subject to any significant $\mathrm{SO}_{4}^{=}$or/and $\mathrm{NO}_{3}^{-}$artifacts.

2.3.1. Sulfate artifacts. For sulfate only positive artifacts have been reported resulting from the conversion of $\mathrm{SO}_{2}$ to $\mathrm{SO}_{4}^{=}$(Lipfert, 1994 and references therein). This conversion is generally most important on alkaline surfaces, i.e., filters (glass fiber) and particles (dust, sea-salt). Since few among our samples have been collected on glass fiber filters two series of extensive tests have been conducted to evaluate possible positive artifacts on the measured nss- $\mathrm{SO}_{4}{ }^{=}$concentrations. During the first one, 4 parallel series of samplings have been carried out using quartz and glass fiber filters. During the second test, 12 series of parallel samplings on glass-fiber, Whatman-41 and Teflon filters have been achieved. Both tests have been performed during spring and summer when $\mathrm{SO}_{4}^{=}$ concentrations are the highest and under N-NW wind conditions with variable wind speed conditions i.e. variable sea-salt amount. In all cases the agreement between the concentrations of nss$\mathrm{SO}_{4}=$ measured by using different types of filters was within $10-15 \%$.

Since the origin of sulfate artifact is its gaseous precursor, the $\mathrm{SO}_{2}$ atmospheric concentrations at Finokalia have been measured during the previously described tests by using the West-Gaeke method (Bonsang, 1982; Putaud et al., 1992). The ambient $\mathrm{SO}_{2}$ levels ranged from $2-5 \mathrm{nmol} / \mathrm{m}^{3}$ $\left(50-120 \mathrm{pptv} ; 1 \mathrm{pptv}=10^{-12} \mathrm{v} / \mathrm{v}\right)$. Such low values clearly indicate absence of local pollution. Based on the above mentioned $\mathrm{SO}_{2}$ concentrations it is found that even if all the $\mathrm{SO}_{2}$ is converted to $\mathrm{SO}_{4}^{=}$, either through reactions with the filter media or the alkaline particles, the maximum $\mathrm{SO}_{4}^{=}$ artifact is expected to be of the order of $0.5 \mu \mathrm{g} / \mathrm{m}^{3}$. This value is at least 5 times lower than the lowest measured value and of the same order of the blank values. Thus, even the $\mathrm{SO}_{4}^{=}$concentrations measured at our sampling station using glass fiber filters are expected to be artifact free due to the very low ambient $\mathrm{SO}_{2}$ levels. It is worthwhile noting that during winter ambient $\mathrm{SO}_{2}$ concentrations could be higher because of lower turnover rates. Thus the effect of ambient $\mathrm{SO}_{2}$ oxidation artifact onto the sulfate pool should be viewed as a lower limit until $\mathrm{SO}_{2}$ measurements during winter become available.

2.3.2. Nitrate artifacts. Unlike $\mathrm{SO}_{4}^{=}, \mathrm{NO}_{3}^{-}$ artifacts could be both negative or positive, representing either a gain or a loss in collected particles. The gain can result from absorption of gaseous $\mathrm{HNO}_{3}$ on the filters (mainly glass fiber) or on already collected particles (Spicer et al., 1982; 
Appel et al., 1984; Pierson et al., 1976). Losses can occur either by thermal decomposition of $\mathrm{NH}_{4} \mathrm{NO}_{3}$ or by reactions of $\mathrm{NH}_{4} \mathrm{NO}_{3}$ or of other nitrates with airborne acids like $\mathrm{H}_{2} \mathrm{SO}_{4}$.

Tests $(n=4)$ on different filter materials showed that $\mathrm{NO}_{3}^{-}$concentrations measured by using quartz filters were roughly $30 \%$ lower than those measured by using glass fiber filters. This difference could be attributed to absorption of $0.8 \mu \mathrm{g} / \mathrm{m}^{3}$ gaseous $\mathrm{HNO}_{3}$ on the alkaline glass fiber filters. Indeed, such atmospheric concentrations of gas phase $\mathrm{HNO}_{3}$ have been measured at Finokalia (Mihalopoulos et al., unpublished data).

A reliable determination of $\mathrm{NO}_{3}^{-}$loss mechanism from filters is difficult since simultaneous gas phase measurements of the $\mathrm{HNO}_{3}$ and $\mathrm{NH}_{3}$ were not continuously performed. Nevertheless the following observations support that the $\mathrm{NO}_{3}^{-}$loss on filters was minor as $\mathrm{NH}_{4} \mathrm{NO}_{3}$ was not formed on aerosol particles.

(i) The $\mathrm{NH}_{4}^{+}$concentrations (see section 3) measured in Finokalia were very low, insufficient to neutralise even the nss- $\mathrm{SO}_{4}^{=}$and it is known that formation of $\mathrm{NH}_{4} \mathrm{NO}_{3}$ mainly occurs after neutralisation of $\mathrm{H}_{2} \mathrm{SO}_{4}$ (Seinfeld, 1992).

(ii) The meteorological conditions prevailing in the area during summer (May to October) were: air temperature $T \approx 25-30^{\circ} \mathrm{C}$ and relative humidity $\mathrm{RH}<50 \%$. Taking into consideration these conditions, the gas phase $\mathrm{HNO}_{3}$ measured concentrations $\left(0.7-1.2 \mu \mathrm{g} / \mathrm{m}^{3}\right.$ preliminary data) and the equilibrium constant of $\mathrm{NH}_{4} \mathrm{NO}_{3}$ (Bassett and Seinfeld, 1983; Mozurkewich, 1993), we calculated mixing ratios of $\mathrm{NH}_{3}$, required to form $\mathrm{NH}_{4} \mathrm{NO}_{3}$, of several tens of ppbv $\left(1 \mathrm{ppbv}=10^{-9} \mathrm{v} / \mathrm{v}\right)$. Such high $\mathrm{NH}_{3}$ mixing ratios have been observed only in areas with important population of cattle (Warneck, 1988), which is definitely not the case of Finokalia. Indeed our preliminary results indicate gas phase $\mathrm{NH}_{3}$ concentrations in the range of $0.2-1.2 \mathrm{ppbv}$, far from the required $\mathrm{NH}_{3}$ values to ensure $\mathrm{NH}_{4} \mathrm{NO}_{3}$ formation. Similar situations of non $\mathrm{NH}_{4} \mathrm{NO}_{3}$ formation have been reported by various authors for Mediterranean (Danalatos et al. 1995) and other areas (i.e. Mehlmann and Warneck, 1995).

(iii) The measured concentrations of $\mathrm{NO}_{3}^{-}$correlate with $\mathrm{Na}^{+}$levels $(r=0.69)$ but not with $\mathrm{NH}_{4}^{+}$. It is worth mentioning that the $\mathrm{NH}_{4}^{+}$concentrations measured with various types of filters showed an agreement within $10-15 \%$. The highest
$\mathrm{NH}_{4}^{+}$levels were measured by using Whatman 41 filters and the lowest by using glass fiber filters.

(iv) Particle size distribution measurements performed during summer in 1995, showed that $\mathrm{NO}_{3}^{-}$ is mainly present in the coarse fractions (Kavouras et al. unpublished data), while $\mathrm{NH}_{4} \mathrm{NO}_{3}$ is expected to predominate in the fine particles fraction.

Finally, the $\mathrm{NO}_{3}^{-}$concentrations measured at Finokalia compare well with those measured at other places in the Mediterranean area using various types of filters (see results and discussion).

\subsection{Meteorological situation}

For the sampling periods data from the meteorological service of Heraklion airport are available. In addition, air mass back trajectories were calculated by using a three dimensional atmospheric transport model (TM2; Heimann and Keeling, 1989; Ramonet et al., 1996) and meteorological data analysed by the European Center for Medium-range Weather Forecast (ECMWF, 1994). Five day back trajectories of air masses arriving at the sampling site at the $850 \mathrm{mbar}$ barometric level were calculated: one for air mass arriving $12 \mathrm{~h}$ before each sampling, two arriving during the sampling period of $24 \mathrm{~h}$ and the last one arriving $12 \mathrm{~h}$ after the end of the sampling. The method used to compute back trajectories of air masses has been described in detail by Ramonet et al. (1996): the transport model is run in a backward mode, i.e. a passive tracer amount is emitted at a location, altitude and time step of the finishing point of the desired back trajectory, and the dispersion of the tracer is computed for 5 days by using inverted 3-D wind fields. The movement of the center of gravity of the air mass provides the air mass trajectory arriving at the station. The back trajectories calculated by the TM2 model were compared successfully with isobaric back trajectories computed by the French Meteorological Office for about 100 cases above the Atlantic ocean (Chiapello I., 1996).

\section{Results and discussion}

\subsection{Air masses back trajectories analysis}

A 6-year climatology study of airflows was performed for the study area in the Eastern 
Mediterranean by using the above mentioned 3-dimensional transport model driven by meteorological fields observed during the studied years and analysed by the European Center of Meteorology and Weather Forecast (ECMWF). 5-day back trajectories ending at Finokalia were calculated for the whole period of 1990-1995 as described in subsection 2.4. The results obtained during the studied period (1994-1995) have been compared with the mean values over 6 years (1990-1995) and have shown the absence of major particularities in the origin of the air masses.

Eleven sectors have been initially defined which, after thorough analysis of the results, were reduced to five main sectors shown in Fig. 2, the local, the north/north-west: N-NW, the west: W, the southwest/south: SW-S, the east: E, and an "unidentified" sector). The local sector extends around Finokalia within a radius of $150 \mathrm{~km}$, covering almost all Crete island. The calculated 5-day back trajectories were then attributed to a sector when they have spent more than $80 \%$ of the last 5-day
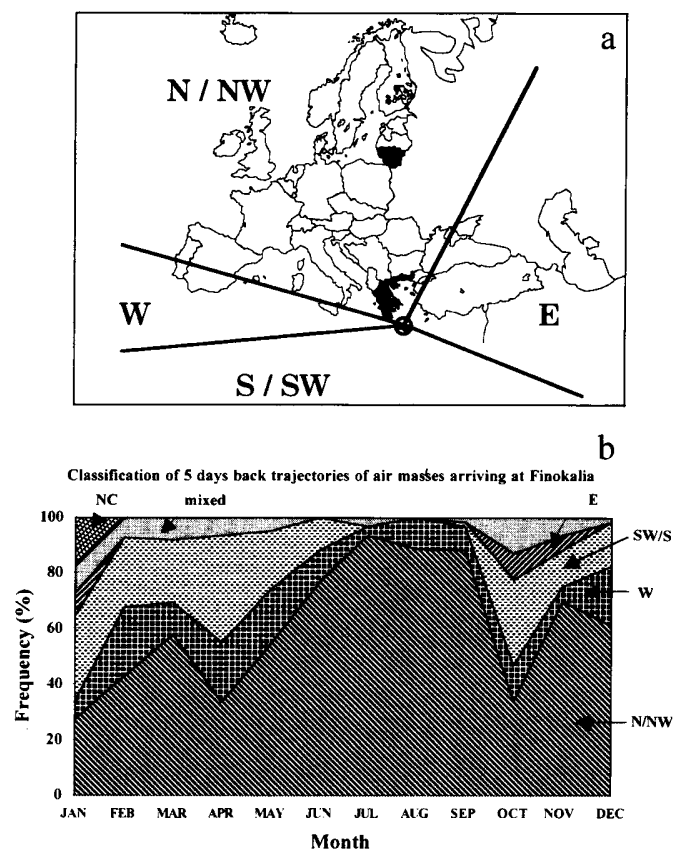

Fig. 2. Classification of back trajectories arriving at Finokalia at the level of 850 mbars during the year 1994. (a) definition of the sectors used for the classification, (b) contribution of each sector to the origin of the air masses ending at Finokalia. period before reaching the sampling site, inside the sector. If this criterion is not reached for any of the defined sectors, then the trajectory was attributed to the "unidentified" sector. The classification of the trajectories in 1994 is presented in Fig. 2. Contrary to the observations in the Western Mediterranean (Bergametti et al., 1989), the Eastern Mediterranean presents a well defined seasonal trend in the origin of the air masses. Following the classification of air-masses trajectories presented in Fig. 2 we concluded about the existence of the following distinct sectors: The $\mathrm{N} / \mathrm{NW}$ which in a yearly basis accounts for about $61 \%$, the W for $13 \%$, the $\mathrm{S} / \mathrm{SW}$ for $18 \%$ and the others for the remaining $8 \%$ of the events. The above classification is in good agreement with the study performed by Dayan (1986) for Israel $\left(35^{\circ} \mathrm{E}, 32^{\circ} \mathrm{N}\right)$.

44 among the 49 collected samples were analysed for all ions and thus ionic balance exists for these samples. To be representative of the above mentioned frequencies of air mass origin, these samples should have the following distribution (in parenthesis the existing): N/NW 27 (30), S/SW 8 (5), W and others 9 (9). Indeed, we observed that although the N/NW sector is slightly over represented by about $10 \%$, the $\mathrm{S} / \mathrm{SW}$ sector is under represented by about $60 \%$.

\subsection{Annual variation of aerosol composition}

Forty nine aerosol samples were collected from March 1994 to April 1995. The median and mean concentrations with the corresponding standard deviations of the measured species are depicted in Table 1 for this period. In Table 2, the median and the mean of the aerosol composition collected within various sectors is presented together with the mean weighted by taking into account the contribution of each sector.

Among the studied species at least $\mathrm{SO}_{4}^{=}, \mathrm{Ca}^{++}$, $\mathrm{K}^{+}$and $\mathrm{Mg}^{++}$can have mixed origin (marine and anthropogenic for $\mathrm{SO}_{4}^{=}$; marine and terrestrial (soil) for $\mathrm{Ca}^{++}, \mathrm{K}^{+}$and $\mathrm{Mg}^{++}$). Assuming that all measured $\mathrm{Na}^{+}$has a marine origin, the sea spray contribution to the observed concentrations of the above mentioned species can be calculated as follows:

nss- $X$ or $X_{\text {excess }}=X_{\text {measured }}-(X / N a) \times(N a)_{\text {measured }}$ where $X$ is the element of interest and $X / N a$ the 
Table 1. Median, mean and standard deviations (S. D.) and non-seasalt components $\left(\mathrm{neq} / \mathrm{m}^{3}\right)$ of aerosols collected at Finokalia, Greece (1994-1995); $n$ is the number of analysed filters

\begin{tabular}{lrrccc}
\hline & & & & Non sea salt \\
Ion & Median & Mean & SD & component & $n$ \\
\hline $\mathrm{Na}^{+}$ & 64.5 & 79.8 & 53 & 0 & 44 \\
$\mathrm{NH}_{4}^{+}$ & 51.9 & 53.7 & 32.2 & 53.7 & 44 \\
$\mathrm{~K}^{+}$ & 10.0 & 11.0 & 5.6 & 8.4 & 44 \\
$\mathrm{Mg}^{++}$ & 15.2 & 17.3 & 9.8 & 0 & 44 \\
$\mathrm{Ca}^{++}$ & 30.8 & 35.4 & 25.5 & 32.2 & 44 \\
$\mathrm{SO}_{4}^{+}$ & 178.3 & 187.9 & 86.2 & 178.3 & 49 \\
$\mathrm{CI}^{-}$ & 14.1 & 38.9 & 47.7 & -40.9 & 49 \\
$\mathrm{NO}_{3}^{-}$ & 20.5 & 24.4 & 18.3 & 24.4 & 49 \\
$\mathrm{MSA}^{-}$ & 0.47 & 0.55 & 0.30 & 0.55 & 49 \\
\hline
\end{tabular}

ratio of its concentration to this of $\mathrm{Na}$ in the sea water given by Brewer (1975).

As shown in Table 1, the sea spray contribution to the measured concentrations ranges from almost $100 \%$ in the case of $\mathrm{Mg}^{++}$to $15 \%$ for $\mathrm{K}^{+}, 10 \%$ for $\mathrm{Ca}^{++}$and $5 \%$ for $\mathrm{SO}_{4}^{=}$. Thus, the marine contribution of $\mathrm{K}^{+}, \mathrm{Ca}^{++}$and $\mathrm{SO}_{4}^{=}$in Finokalia (Eastern Mediterranean) aerosols is minor.

On the other hand, the $\mathrm{Cl}^{-} / \mathrm{Na}^{+}$ratio in aerosols (0.49) is lower by a factor of 2.5 than this ratio in the seawater (1.18), indicating thus a deficit of $\mathrm{Cl}^{-}$relative to $\mathrm{Na}^{+}$. This situation has also been observed in previous studies conducted at coastal areas (Yoshizumi and Hoshi, 1985; Wall et al., 1988) and is explained by the reactions of acids with sea salt following the equation (Eriksson, 1960; Junge, 1963; Bruynseels and Van Grieken, 1985):

$$
\mathrm{NaCl} \text { particles }+H_{\text {gas }}^{+} \rightarrow H_{\text {particles }}^{+}+\mathrm{HCl}_{\text {gas }} \text {. }
$$

Concentrations of aerosol composition measured over Corsica, in Western Mediterranean (over a period of 18 months), as well as from other rural sites are also reported in Table 2. Comparison of our results with earlier published data leads to the following remarks.

(a) Nss- $\mathrm{SO}_{4}^{=}$concentrations in Finokalia, accounting for about $95 \%$ of the total $\mathrm{SO}_{4}^{=}$ concentrations, are around $25 \%$ higher than those observed in Corsica. However, our results agree very well with observations at Hazelrigg in England (Harrison and Pio, 1983). It is worthwhile to note that such nss- $\mathrm{SO}_{4}=$ values are among the highest reported for rural places in Europe and are comparable with values observed in urban areas (OECD, 1977 and references therein). In addition, Tsitouridou and Samara (1993) reported for Thessaloniki (the second most important urban center of Greece) nss-SO ${ }_{4}{ }^{-}$values of 196 $\mathrm{neq} / \mathrm{m}^{3}$.

(b) $\mathrm{NO}_{3}^{-}$and $\mathrm{NH}_{4}^{+}$are the two main inorganic nitrogen species. Their annual mean concentrations at Finokalia, $24.4 \mathrm{neq} / \mathrm{m}^{3}$ and $53.7 \mathrm{neq} / \mathrm{m}^{3}$

Table 2. Comparison of major ionic species concentrations between Finokalia ( $m e d .=$ median, mea.= mean) and other stations; all species in $n e q / \mathrm{m}^{3}$

\begin{tabular}{|c|c|c|c|c|c|c|c|c|c|c|c|}
\hline \multirow[b]{2}{*}{ Ion } & \multicolumn{2}{|c|}{$\begin{array}{l}\text { Finokalia } \\
\text { weighted } \\
\text { all sectors }\end{array}$} & \multicolumn{2}{|c|}{$\mathrm{N} / \mathrm{NW}$} & \multicolumn{2}{|c|}{ W } & \multicolumn{2}{|c|}{$\mathrm{S}$} & \multirow{2}{*}{$\begin{array}{l}\text { W. Medi- } \\
\text { terranean }\end{array}$} & \multirow{2}{*}{$\begin{array}{l}\text { Hazelrigg } \\
\text { (UK) }\end{array}$} & \multirow{2}{*}{$\begin{array}{l}\text { Japan (4) } \\
\text { (3) }\end{array}$} \\
\hline & med. & mea. & med. & mea. & med. & mea. & med. & mea. & & & \\
\hline $\mathrm{NA}^{+}$ & 70.2 & 85.3 & 64.5 & 80.6 & 60.4 & 64.5 & 96.8 & 116.4 & $43.4(1)$ & 80 & $20.9-32.2$ \\
\hline $\mathrm{NH}_{4}^{+}$ & 49.8 & 52.0 & 53.2 & 58.5 & 36.3 & 36.8 & 47.8 & 40.9 & - & 240 & $37.6-51.8$ \\
\hline $\mathrm{K}^{+}$ & 10.6 & 11.1 & 11.1 & 11.7 & 7.3 & 7.8 & 11.2 & 11.4 & $5.7(1)$ & 6.0 & $3.3-8.5$ \\
\hline $\mathrm{Mg}^{+}$ & 15.4 & 17.1 & 14.2 & 17.4 & 14.1 & 14.3 & 20.6 & 17.9 & - & 18 & $8.3-11.7$ \\
\hline $\mathrm{Ca}^{++}$ & 35.2 & 37.4 & 27.6 & 28.4 & 22.0 & 26.3 & 70.5 & 75.9 & $12.7(1)$ & 27.0 & $35.5-59.5$ \\
\hline nss-SO ${ }_{4}^{=}$ & 162.3 & 170.9 & 184.5 & 192.7 & 123.2 & 132.1 & 115.3 & 125 & $96.4(1)^{*}$ & $172.7^{*}$ & $73.3-81.0^{*}$ \\
\hline $\mathrm{Cl}^{-}$ & 21.2 & 38.5 & 10.5 & 34.5 & 14.1 & 29.7 & 62.4 & 58.2 & - & 119 & $13.8-29.3$ \\
\hline $\mathrm{NO}_{3}^{-}$ & 21.7 & 24.4 & 21.7 & 23.7 & 19.0 & 21.9 & 23.8 & 28.6 & $20.6(2)$ & 85 & $12.7-19.1$ \\
\hline $\mathrm{MSA}^{-}$ & & 0.55 & & & & & & - & & - & $0.03-1(5)$ \\
\hline
\end{tabular}

(1) Bergametti et al. (1989); (2) Alarcon and Cruzado (1988) i(3) Harrison and Pio (1983); (4) Kaneyasu et al. (1995); (5) Mukai et al. (1995).

*Calculated from reported $\mathrm{SO}_{4}^{=}$and $\mathrm{Na}^{+}$concentrations. 
respectively, are 3.5 and 4.5 times lower than those observed at Hazelrigg (Harrison and Pio, 1983). However, such low $\mathrm{NO}_{3}^{-}$values have also been observed at the center of Thessaloniki (31.5 neq $/ \mathrm{m}^{3}$ ) and Patras ( $25 \mathrm{neq} / \mathrm{m}^{3}$; Danalatos et.al., 1995) using various filter media such as Teflon and Whatman-41. Few published data exist for the Western Mediterranean. Low $\mathrm{NO}_{3}^{-}$concentrations have also been reported in Majorca (15.9 neq $/ \mathrm{m}^{3}$; Simo et al., 1991) and Blanes (20.6 neq $/ \mathrm{m}^{3}$; Alarcon and Cruzado, 1988) in the North Western Mediterranean. As Majorca station is located at an altitude of $1000 \mathrm{~m}$, it is not clear if the reported data are representative of the boundary layer or of the free troposphere.

The low measured $\mathrm{NH}_{4}^{+}$values are in agreement with those observed at Patras (Danalatos et al., 1995).

(c) Methanesulfonate (MSA) concentrations range from 0.07 to $1.31 \mathrm{nmol} / \mathrm{m}^{3}$. To our knowledge, those are the first data of MSA reported for the whole Mediterranean area. The observed MSA concentrations are very similar to the previously reported data at similar latitudes in both hemispheres, such as Norfolk Island (Pacific; 0.05-0.6; Saltzman et al., 1986), Cape Grim (Tasmania; 0.05-1; Ayers et al., 1986) and OKI islands (Japan; 0.03-1; Mukai et al., 1995). MSA is an oxidation product of biologically produced dimethylsulfide (DMS). MSA concentrations are used in Subsection 3.5. to evaluate the contribution of the marine source to the sulfur budget in Eastern Mediterranean.

\subsection{Seasonal variations of aerosol ionic composition}

The seasonal variations of nss- $\mathrm{SO}_{4}=$, MSA, and $\mathrm{Na}^{+}$, species characteristic of anthropogenic influence, marine biological activity and sea spray, respectively, are shown in Figs. 3.2 different groups of ions were identified. $\mathrm{Na}^{+}$presents maxima concentrations in winter and spring linked to the observed local wind speed, in agreement with the observations in Corsica (Bergametti et al., 1989). MSA presents similar to nss- $\mathrm{SO}_{4}^{=}$ trend with maxima in summer. This could lead to misinterpretation since nss- $\mathrm{SO}_{4}^{-}$can have both biogenic and anthropogenic origin. We evaluated (see Subsection 3.5) the mean biogenic part of nss$\mathrm{SO}_{4}^{=}$to be less than $8 \%$. The observed seasonal trend of sulfur containing ions can be explained
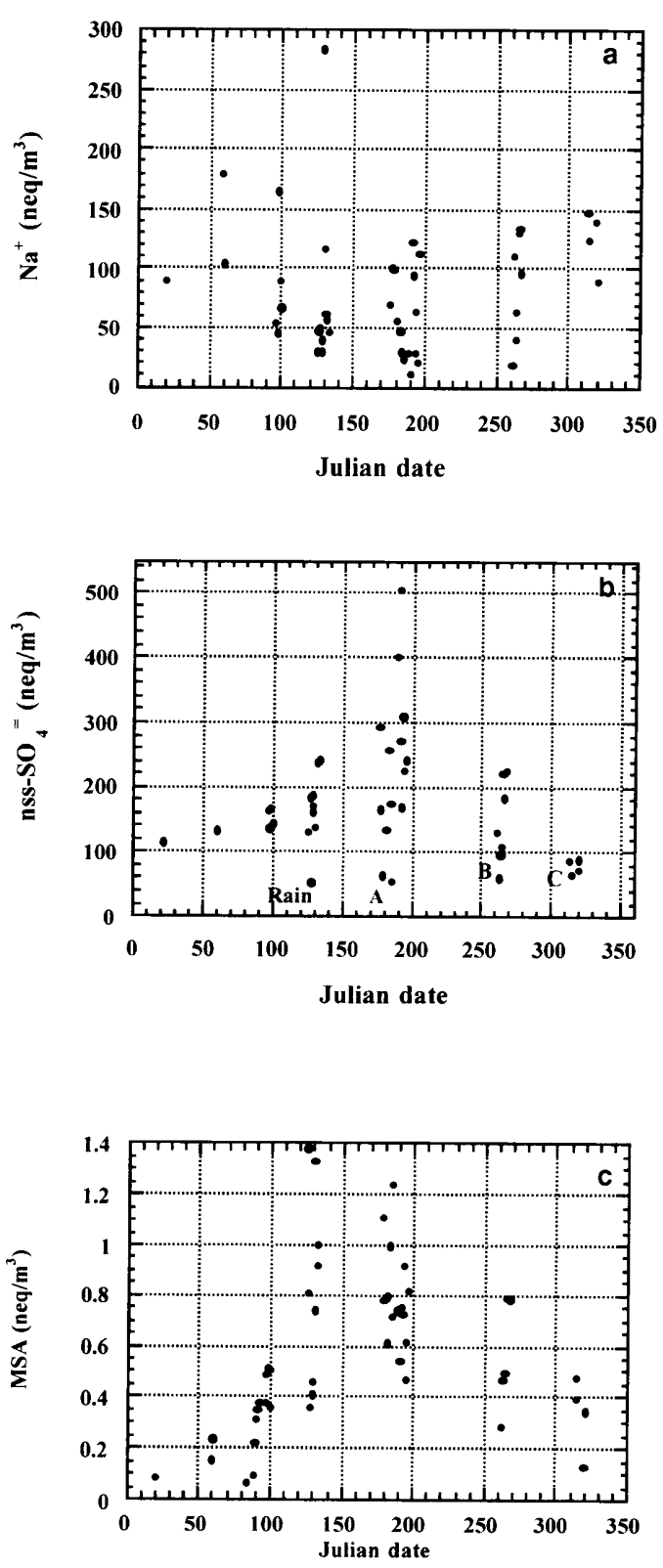

Fig. 3. Seasonal variation of $\mathrm{Na}^{+}$(a), nss-SO $\mathrm{SO}_{4}^{=}$(b) and MSA (c) concentrations in aerosol samples collected at Finokalia. 'Rain' indicates sample affected by rain. A, B, C correspond to samples collected in air masses with well distinguished origine (see text, sub section 3.3).

by changes (1) in the removal rate of atmospheric particles, (2) in the airflow patterns, and (3) in the source emission strength. 
It is well known that the Eastern Mediterranean is characterised by two distinct climatic periods: the dry period from mid May to mid September, and the rainy period from October to May. Figs. $3 \mathrm{~b}, \mathrm{c}$ clearly show that nss-SO ${ }_{4}=$ and MSA present their maxima during the dry period, when the absence of precipitation largely increases the lifetime of aerosols since dry deposition is then their only possible removal mechanism. During this period the wet removal of $\mathrm{SO}_{2}$, precursor of nss$\mathrm{SO}_{4}^{=}$, is minimum. Thus the conversion ratio of $\mathrm{SO}_{2}$ to particulate nss- $\mathrm{SO}_{4}^{=}$becomes maximum. The effect of rain is obvious on a sample collected during May 1994 (Fig. 3b).

However, it is obvious (Fig. 3b) that during summer the nss- $\mathrm{SO}_{4}^{=}$concentrations were significantly higher than those observed during autumn, a period also with a relative absence of precipitations. The use of air-mass trajectories allows an explanation for this difference. As it is shown in Fig. 2, during autumn the contribution of southern sector becomes more important. Thus the lowest values observed during November (noted with the symbol C) were associated with transport from the south (see also Fig. 7a). Airmass trajectories could also explain the difference observed during a period with no significant change in the air mass origin. This is the case of the samples collected during the June-July period. Although during this period the air masses were originated from N/NW Europe (see also Fig. 7c), the lowest values (noted with the symbol A) correspond to air masses originating from the free troposphere and thus the influence of surface sources was minimum. Finally the low values observed during autumn 1994, and noted with the symbol B, were associated with air masses travelling above the sea for $48 \mathrm{~h}$ before arrival to Finokalia (see also Fig. 7b).

Removal from the atmosphere and variation in airflow patterns is not the only mechanism responsible for the observed seasonality of MSA, since MSA presents a second maximum in May. Seasonal changes in source emission strength can significantly affect the observed seasonality. MSA is a product of the atmospheric oxidation of the gaseous DMS produced in seawater as a result of the interactions between phytoplankton, zoo plankton and bacteries (Belviso et al. 1990; Groene, 1995). Thus, atmospheric MSA variations reflect partly the seasonal pattern of the DMS source (Ayers et al., 1991). To our knowledge there are no reported data on the seasonal variation of DMS in the Eastern Mediterranean seawater. In the Western Mediterranean a maximum of seawater DMS was observed during the May-June period, in agreement with our observations (Belviso S., personal communication, 1996). However, the Eastern Mediterranean Sea is oligotrophic compared to Western Mediterranean and other areas in the world for which MSA data are available. Therefore, data on the seasonal variation of DMS in the seawater and the atmosphere are clearly needed for the Eastern Mediterranean sea (ongoing work).

\subsection{Ionic balance}

The most important alkaline species are nss$\mathrm{Ca}^{++}$and $\mathrm{NH}_{4}^{+} . \mathrm{NH}_{4}^{+}$correlates very well with nss- $\mathrm{SO}_{4}^{-}\left(r^{2}=0.85 ; r=0.92\right.$; Fig. 4$)$ indicating that the majority of $\mathrm{NH}_{4}^{+}$is neutralised by nss$\mathrm{SO}_{4}^{=}$. However, the slope of the regression which is only 0.32 (or 0.26 when the two points with nss$\mathrm{SO}_{4}^{=}>320 \mathrm{neq} / \mathrm{m}^{3}$ are removed) indicates that only partial neutralisation of $\mathrm{H}_{2} \mathrm{SO}_{4}$ can occur and suggests that mainly $\mathrm{NH}_{4} \mathrm{HSO}_{4}$ was formed instead of $\left(\mathrm{NH}_{4}\right)_{2} \mathrm{SO}_{4}$. Nss-Ca ${ }^{++}$and nss- $\mathrm{K}^{+}$can also neutralise a part of $\mathrm{H}_{2} \mathrm{SO}_{4}$. However, the nss$\left(\mathrm{Ca}^{++}+\mathrm{K}^{+}\right) /$nss-SO ${ }_{4}^{=}$ratio is only 0.23 indicating also only partial neutralisation of $\mathrm{H}_{2} \mathrm{SO}_{4}$ by nss- $\mathrm{Ca}^{++}$and $\mathrm{K}^{+}$. Thus, the $45 \%$ of nss$\mathrm{SO}_{4}^{=}(1-(0.32+0.23))$ are not neutralised by any of the measured cations and might be present in

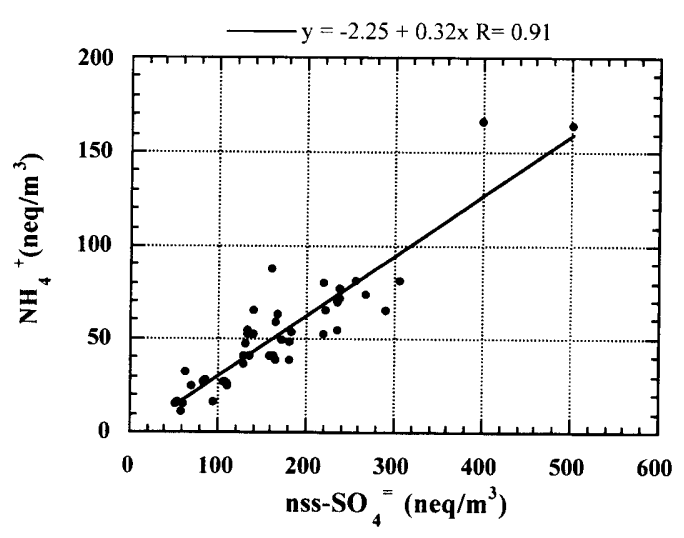

Fig. 4. Observed correlation between nss- $\mathrm{SO}_{4}^{=}$and $\mathrm{NH}_{4}^{+}\left(\mathrm{neq} / \mathrm{m}^{3}\right)$. 


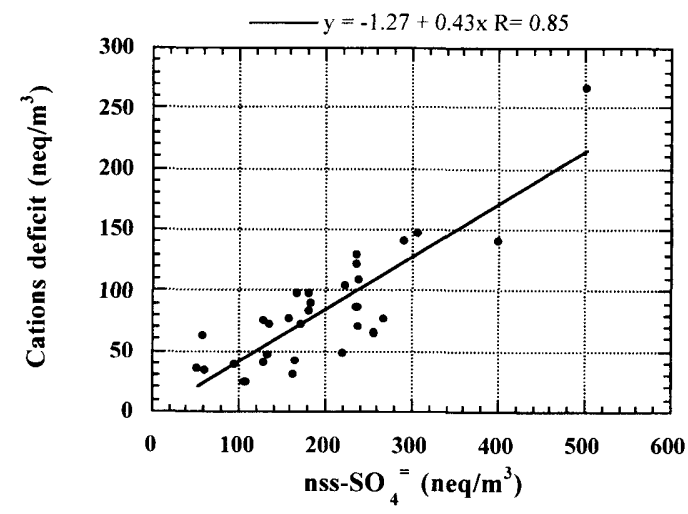

Fig. 5. Aerosol cation deficit versus nss- $\mathrm{SO}_{4}^{=}$concentration $\left(\mathrm{neq} / \mathrm{m}^{3}\right)$.

acidic form $\left(\mathrm{H}_{2} \mathrm{SO}_{4}\right)$. Similar results have been obtained by Mehlmann and Warneck (1995). In this case, a significant concentration of hydrogen cations must be present in the aqueous solution associated with the aerosols. As hydrogen ions cannot be measured directly, their presence will be shown as a deficit of cations relative to the measured anions. Indeed, when examining the anion/cation charge balance, we calculated the ratio of the sum of anions to the sum of cations (in terms of equivalents) found in each sample. Thus, a mean value of 1.37 is calculated, which is significantly higher than unity and indicates a net deficit of cations when compared to anions. In Fig. 5, we have plotted the cation deficit, defined as an excess of negative charge (=the sum of anions minus the sum of cations; expressed in equivalents), versus the concentration of nss$\mathrm{SO}_{4}^{-}$. We considered as deficit only the values above $\pm 20 \mathrm{neq} / \mathrm{m}^{3}$, corresponding to an experimental error of $10 \%$ ( $5 \%$ for anions and cations respectively). The intercept is not significantly different from zero. On the other hand, the slope (neq of cation deficit/ neq of nss-SO ${ }_{4}^{=}$) is 0.43 $( \pm 0.03)$ and the correlation coefficient is 0.85 . Thus, each equivalent of nss-SO ${ }_{4}^{=}$measured in our samples indicates the presence of 0.43 equivalent of $\mathrm{H}^{+}$as well. This value is in good agreement with our previous conclusion that about $45 \%$ of $\mathrm{H}_{2} \mathrm{SO}_{4}$ was in acidic form.

Fig. 6 presents the variation of the cation deficit as a function of time. Three situations can be observed: (a) the existence of negative values corresponding to an anion deficit; (b) situations with

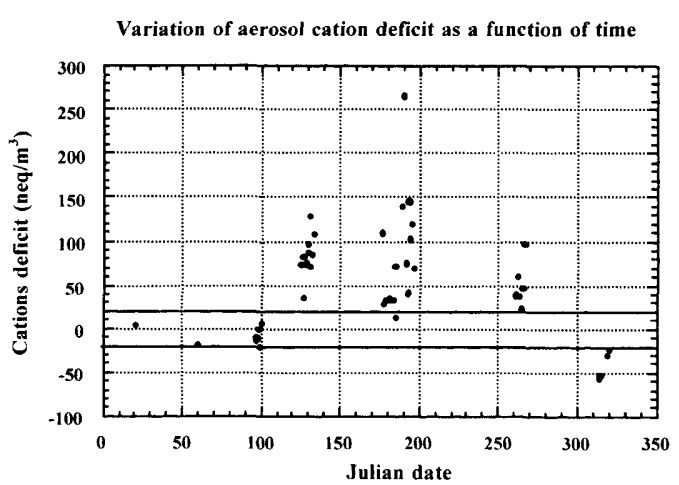

Fig. 6. Variability of aerosol cation deficit (neq $\left./ \mathrm{m}^{3}\right)$ as a function of time.

deficit ranging between $\pm 20 \mathrm{neq} / \mathrm{m}^{3}$ which, as mentioned above, are considered as balanced; (c) positive values which account for the majority of the studied events. 5-day back trajectory analysis was used to explain the above observations.

The anion deficit corresponds to transport of air masses from Africa (Fig. 7a). It is well known that such air masses are rich in $\mathrm{CaCO}_{3}$. Nss$\mathrm{SO}_{4}^{=}$concentrations are not enough to neutralise the $\mathrm{Ca}^{++}$leading to a deficit of anions which is attributed to the presence of $\mathrm{HCO}_{3}^{-}$, not measurable by ion chromatography (Losno et al., 1991). In this case the mean value of nss-SO ${ }_{4}^{=}(127.8 \pm 29$ $\mathrm{neq} / \mathrm{m}^{3}, n=5$ ) is significantly lower than the nss$\mathrm{SO}_{4}^{=}$mean value for all samples.

In the case of no significant ion deficit, again the mean value of nss-SO $\mathrm{SO}_{4}^{=}\left(140.4 \pm 39 \mathrm{neq} / \mathrm{m}^{3}\right.$, $n=9$ ) is significantly lower than the nss- $\mathrm{SO}_{4}^{=}$mean value for all samples. The majority of such events correspond to situations with air masses having spent 1-2 days over the sea (Fig. 7b). Another category contains events occurring mainly during the rainy period. Atmospheric aerosols were, therefore, removed partially from the air masses before reaching Crete.

The third case with deficit significantly different from zero corresponds to transport from Western or Northern Europe (Fig. 7c). The majority of events occurs during the dry period and thus long range transport is the main reason of the observed high nss-SO $\mathrm{SO}_{4}^{=}$values $\left(203.1 \pm 94.3 \mathrm{neq} / \mathrm{m}^{3}, n=30\right)$.

\subsection{Anthropogenic versus biogenic sulfur source}

Based on the measured MSA concentrations, a first picture of the relative contribution of biogenic 
a)

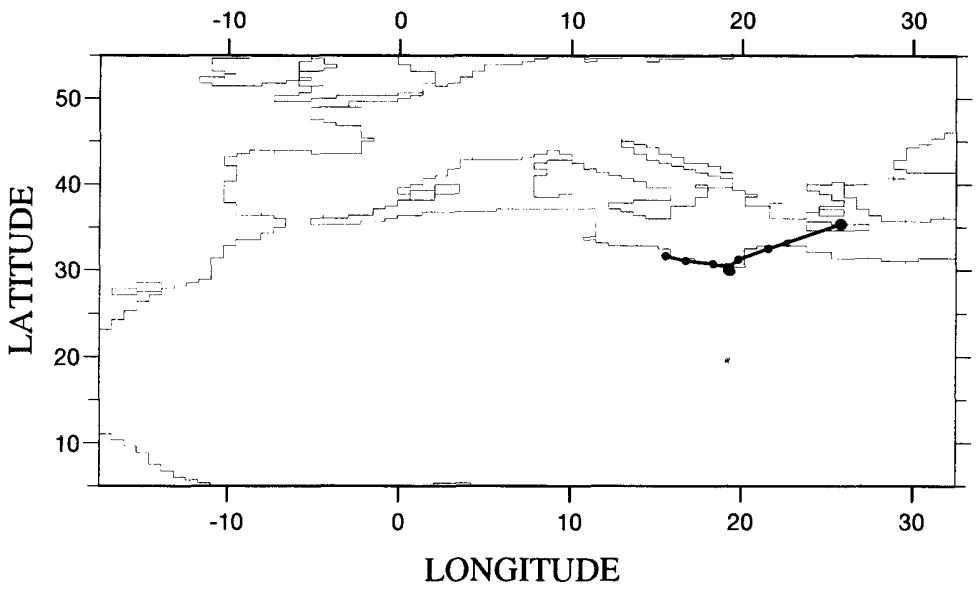

b)

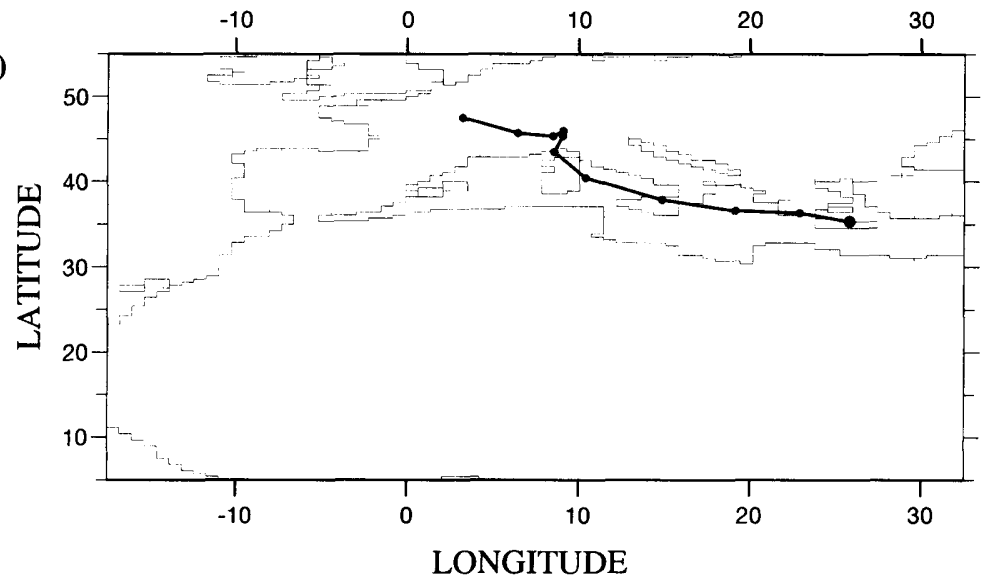

c)

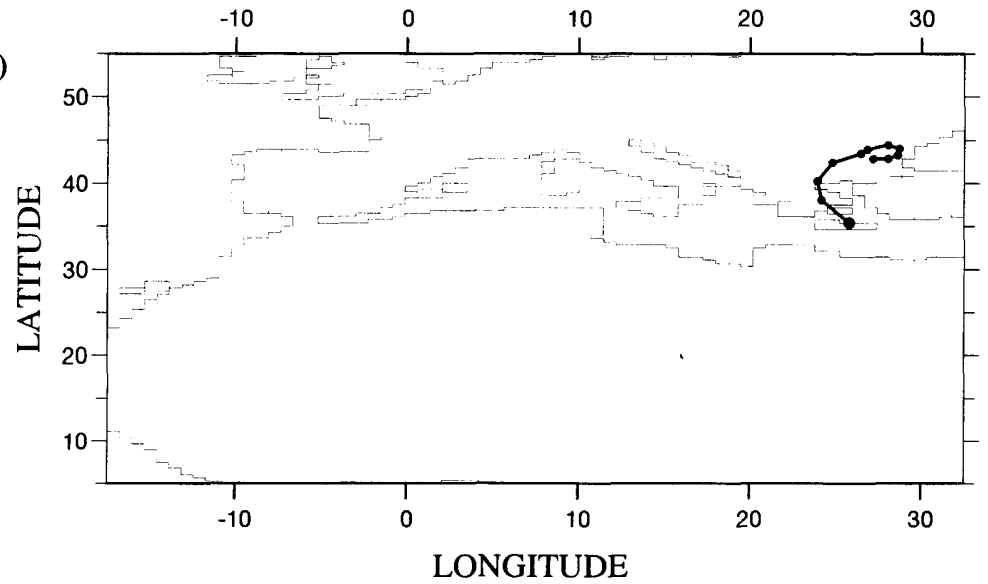

Fig. 7. 850 mbar back trajectories arriving at Finokalia for events corresponding to (a) transport from Sahara, (b) transport over the Western Mediterranean sea and (c) transport from Northern Europe. 
and anthropogenic sources to the sulfur cycle in the east Mediterranean region can be emerged. MSA produced from the oxidation of dimethyl sulfide (DMS), has exclusively biogenic origin. Nss- $\mathrm{SO}_{4}^{=}$is partly formed by DMS oxidation. Thus, if the molar ratio of $\mathrm{MSA} / \mathrm{nss}-\mathrm{SO}_{4}^{=}$from this biogenic source is known, then the parts of nss- $\mathrm{SO}_{4}^{=}$originating from biogenic and anthropogenic sources can be calculated. However, the $\mathrm{MSA} / \mathrm{nss}^{-\mathrm{SO}_{4}}=$ ratio is not constant and varies as a function of latitude and $\mathrm{NO}_{x}$ concentrations (Bates et al., 1992; Patroescu J., Barnes I., Becker K. H., and Mihalopoulos N., unpublished results). Using the Bates et al. (1992) empirical equation which relates the $\mathrm{MSA} / \mathrm{nss}-\mathrm{SO}_{4}^{=}$ratio to temperature under oceanic conditions (low $\mathrm{NO}_{x}$ levels), we calculate an MSA/nss-SO $=$ order of 0.1 . This ratio has to be viewed as the lower value since the presence of $\mathrm{NO}_{x}$ will enhance the MSA concentration (Barnes et al., 1988). Patroescu et al. (1996) give an empirical relation between the $\mathrm{MSA} / \mathrm{nss}-\mathrm{SO}_{4}=$ molar ratio and the $\mathrm{NO}_{x}$ concentrations. Unfortunately, no measurement of the $\mathrm{NO}_{x}$ concentrations in the Eastern Mediterranean exists. Thus, on the basis of the $\mathrm{NO}_{x}$ values computed by a 3 dimensional global model (Kanakidou and Crutzen, 1993) and the empirical relationship given by Patroescu et al. (1996), the above calculated $\mathrm{MSA} / \mathrm{nss} \mathrm{SO}_{4}{ }^{=}$ratio could be higher by a factor of 2 . Based on this molar ratio $(0.1-0.2)$ and the range of MSA concentrations measured at Finokalia $\left(0.1-1.1 \mathrm{nmol} / \mathrm{m}^{3}\right)$, we calculate biogenic nss$\mathrm{SO}_{4}^{=}$concentrations ranging from 0.5 to $11 \mathrm{nmol} / \mathrm{m}^{3}$. These values account for the 0.6 to $28.3 \%$ of the nss- $\mathrm{SO}_{4}=$ concentrations measured at the site (mean values are $3.7 \pm 3.1$ and $7.8 \pm 6.3$ for $\mathrm{MSA} / \mathrm{nss}^{-\mathrm{SO}_{4}}=$ ratio of 0.2 and 0.1 respectively). A clear seasonal signal also exists with lighter values during summer months (May to July), in line with the observed MSA concentrations, and could be due to the higher phytoplanktonic activity during the summer period.

\section{Conclusion}

The concentrations of the major soluble ions, sulfate, nitrate, chloride, methanesulfonate, sodium, ammonium, potassium, calcium and magnesium have been measured in 49 aerosol samples collected over a year at the coastal site of Finokalia, on the island of Crete in the Eastern Mediterranean. The measured mean nss-SO ${ }_{4}^{=}$concentration is among the highest reported for rural areas in Europe and is comparable to values observed over urban areas. The highest concentrations are associated with transport from Eastern and Central Europe and occur during the dry period when dry deposition is the main removal mechanism from aerosol particles.

According to our observations at Finokalia, $\mathrm{NH}_{4}^{+}$and $\mathrm{Ca}^{++}$concentrations were not sufficient to neutralise the measured nss- $\mathrm{SO}_{4}^{=}$concentrations and a cation deficit correlated with the nss$\mathrm{SO}_{4}^{=}$concentrations was calculated. The highest deficit was associated with transport from Western and Central Europe and occurred during the dry period. At least $40-50 \%$ of nss- $\mathrm{SO}_{4}^{=}$exist in the form of $\mathrm{H}_{2} \mathrm{SO}_{4}$ which would influence the acidity of rainwater. Measurements of the composition of rain water are on going to further confirm the above statement.

From the coexamination of factors like the meteorological conditions prevailing in the sampling area especially during summer, the $\mathrm{HNO}_{3}$ atmospheric concentrations and the $\mathrm{NH}_{4} \mathrm{NO}_{3}$ formation rate, we excluded that the later could be formed.

Based on the MSA/nss- $\mathrm{SO}_{4}^{=}$molar ratio and the MSA concentrations, we evaluated that biogenic sulfur compounds account for 0.6 to $28.3 \%$ of the total nss- $\mathrm{SO}_{4}^{=}$concentrations measured at Finokalia, with the higher values occurring during the summer months. However, observations during more extended and continuous periods (year-round) are needed to assess the relative importance of the factors controlling the aerosol composition in the Eastern Mediterranean.

\section{Note added}

After this article was accepted, we became aware of the new measurements of particulate sulfate at various locations in Israel by Luria et al. (1996), who likewise present high $\mathrm{SO}_{4}^{=}$concentrations with seasonal variations in agreement with our observations. 


\section{Acknowledgements}

We thank E. Baboukas, G. Kouvarakis, A. Gogou and I. Kavouras for their technical assistance and Dr. B. Bonsang for constructive discussions. This work was supported by the EU CT92-0824 SCIENCE and the ENV4 CT95-0036 (MEDUSE) programmes, the Research Account of the University of Crete and the Programme FrancoHéllénique de Cooperation Scientifique. Acknowledged are the organisation for the Development of Eastern Crete (O.AN.A.K) and the General Secretariat of the Region of the Crete for the financing and construction of the sampling tower at Finokalia. M. K. and P. B. express gratitude to the CNRS, the CEA and the IDRIS for support.

\section{REFERENCES}

Alarcon, M. and Cruzado, A. 1988, Monitoring of aerosol composition at a Catalan coastal site of North Western Mediterranean. In: Field measurements and their interpretation, Beilke S., Morelli J., and Angeletti G. (eds.). EUR 11690. E. Gyuot S. A. Brussels, 101-118.

Appel, B., Tokiwa, Y., Haik, M. and Kothly E. L. 1984, Aritfact particulate sulfate and nitrate formation of filter media. Atmos. Environ. 18, 409-416.

Arnold, M., Seghaier, A., Martin, D., Buat-Menard, P. and Chesselet, R. 1982. Geochemistry of the marine aerosol over the Western Mediterranean Sea. In: Comptes Rendus des VI journées d'études sur les pollutions marines en Mediterranée. CIESM Monaco, 37-37.

Ayers, G. P., Ivey, J. P. and Goodman, H. S., 1986, Sulfate and methanesulfonate in the maritime aerosol at Cape Grim, Tasmania. J. Atmos. Chem. 4, 173-185.

Ayers, G. P., Ivey, J. P. and Gillett, R. W. 1991. Coherence between seasonal cycles of dimethyl sulfide, methanesulphonate and sulphate in marine air. Nature 349, 404-406.

Barnes, I., Bastian, V. and Becker, K. H. 1988. Kinetics and mechanisms of the reaction of $\mathrm{OH}$ radicals with dimethyl sulfide. Int. J. Chem. Kinet. 20, 415-431.

Bassett, M. and Seinfeld, J. H. 1983. Atmospheric equilibrium model of sulfate and nitrate aerosols. Atmos. Environ. 17, 2237-2252.

Bates, T. S., Calhoun, J. A. and Quinn, P. K. 1992. Variations in the methanesulfonate to sulfate molar ratio in submicrometer marine aerosol particle over the South Pacific ocean. J. Geophys. Res. 97, 9859-9865.

Belviso, S., Kim, S. K., Rassoulzadegan, F., Krajka, B., Nguyen, B. C., Mihalopoulos, N. and Buat-Menard, P. 1990. Production of dimethylsulfonium propionate (DMSP) and dimenthylsulfide (DMS) by a microbial food web. Limnol. Oceanogr. 35, 1810-1821.

Bergametti, G., Dutot, A. L., Buat-Menard, P., Losno, R. and Remoudaki, E. 1989. Seasonal variability of the elemental composition of atmospheric aerosol particles over the North Western Mediterranean atmosphere. Tellus 41B, 353-361.

Bonsang, B. 1982. Cycle atmosphérique du soufre d'origine marine. PhD Thesis. University of Picardie, $182 \mathrm{p}$.
Brewer, P. G. 1975. Minor elements in sea water. In: Chemical oceanography 1 Academic Press, New York, 417p.

Bruynseels, F. and Grieken, V. 1985. Direct detection of sulfate and nitrate levels on sampled marine aerosols by laser microprobe analysis. Atmos. Environ. 19, 1969-1970.

Charlson, R. J., Langner, J., Rodhe, H., Leovy, C. B. and Warren, S. G. 1991. Perturbation of the northern hemisphere radiative balance by backscattering from anthropogenic sulfate aerosols. Tellus 43AB. 152-163.

Chiapello, I. 1996. Les aérosols atmosphériques au-dessus de l'Atlantique nord tropical: approche physicochimique et météorologique. Evaluation de la contribution des différentes espèces à l'épaisseur optique en aérosol. Thèse de Sciences, Univ. Paris 7.

Danalatos, D., Glavas, S. and Kambezidis, H. 1995. Atmospheric nitric acid concentrations in a Mediterranean site, Patras, Greece. Atmos. Environ. 29, 1849-1852.

Dayan, U. 1986. Climatology of back trajectories from Israel based on synoptic analysis. J. Appl. Meteorol. 25, 591-595.

Dulac, F., Buat-Menard, P., Arnold, M. and Ezat, U. 1987. Atmospheric input of trace metals to the Western Mediterranean Sea (1) factors controlling the variability of atmospheric concentrations. Geophys. Res. Lett. 92, 8437-8453.

Erikson, E. 1960. The yearly circulate of chloride and sulfur in nature: meteorological, geochemical and pedological implications. Part II. Tellus 12, 63-109.

ECMWF, 1994. The description of the ECMWF/WRCP level $I I I-A$. Global atmospheric data archive. European Centre for Medium-Range weather Forecast.

Ganor, E. and Mamane, Y. 1982. Transport of Saharan dust across the Eastern Mediterranean. Atmos. Environ. 16, 581-587.

Gogou, A., Stephanou, E., Stratigakis, N., Grimalt, J. O., Simo, R., Aceves, M. and Albaiges J. 1994. Differences in lipid and organic salt constituents of aerosols from Eastern and Western Mediterranean coastal sites. Atmos. Environ. 28, 1301-1310.

Groene, T. 1995. Biogenic production and consumption of dimethylsulfide (DMS) and dimethylsulfoniopropionate (DMSP) in the marine epipelagic zone: a review. J. Marine Systems 6, 191-209. 
Harrison, R. and Pio, C. 1983. Major ion compositon and chemical associations of inorganic atmospheric aerosols. Environ. Sci., Technol. 17, 169-174.

Heimann, M. and Keeling, C. D. 1989. A threedimensional model of atmospheric $\mathrm{CO}_{2}$ transport based on observed winds: Model description and simulated tracer experiments. Geophys. Mono. 55, 237-275.

IPCC, 1994. Climate change 1994. Radiative forcing of climate change and an evaluation of the IPCC IS92 Emission Scenarios. J. T. Houghton, L. G. Meira Filho, J, Bruce, Hoesung Lee, B. A. Callander, H, Haites, $\mathrm{N}$, Harris, and $\mathrm{K}$, Maskell (eds.). Cambridge University Press, 1995.

Junge C. 1963. Air chemistry and radioactivity. Academic press, New York.

Kanakidou, M. and Crutzen, P. J. Scale problems in global tropospheric chemistry modeling. Comparison of results obtained with a three-dimensional model, adopting longitudinally uniform and varying emissions of $\mathrm{NO}_{x}$ and NMHC. Chemosphere 26, 787-802, 1993.

Kaneyatu, N., Ohta, S. and Murao, N. 1995. Seasonal variation in the chemical composition of atmospheric aerosols and gaseous species in Sapporo, Japan. Atmos. Environ. 29, 1559-1568.

Keene, W. C., Pszenny, A. A. P., Jacob, D. J., Duce, R. A., Galloway, J. N., Schultz-Tokos, J. J., Sievering, H. and Boatman, J. F. 1990. Global Biogeochemical Cycles 4, 407-430.

Kirkitsos P. D. and Sikiotis D. 1991. Nitric acid, ammonia and particulate nitrates, sulfates and ammonium in the atmosphere of Athens. Ekistics 34, 156-163.

Lipfert, F. 1994. Filter artifacts associated with particulate measurements: recent evidence and effects on statistical relationships. Atmos. Environ. 28, 3233-3249.

Losno, R., Bergametti, G., Carlier, P. and Mouvier, G. 1991. Major ions in marine rainwater with attention to sources of alkaline and acidic species. Atmos. Environ. 25A. 763-770.

Luria, M., Peleg, M., Sharf G., Siman Tov-Alper, D., Spitz, N., Ben Ami, T., Gawii, Z., Lifschitz, B., Yitzchaki, A. and Seter, I. 1996. Atmospheric sulfur over the East Mediterranean region. J. Geophys. Res. 101, 25917-25930.

Mamane, Y., Ganor, E. and Donagi, A. E. 1980. Aerosol composition of urban and desert origin in the Eastern Mediterranean (I). Individual particle analysis. Water, Air, and Soil Pollution 14, 29-43.

Mamane, Y., Ganor, E. and Donagi, A. E. 1982. Aerosol composition of urban and desert origin in the Eastern Mediterranean (II). Deposition of large particles. Water, Air, and Soil Pollution 18, 475-484.

Mehlmann, A. and Warneck, P. 1995. Atmospheric gaseous $\mathrm{HNO}_{3}$, particulate nitrate and aerosol size distributions of major ionic species at a rural site in Western Germany. Amos. Environ. 29, 2359-2373.
Mozurkewich, M. 1993. The dissociation constant of ammonium nitrate and its dependence on temperature, relative humidity and particle size. Atmos. Environ. 27, 261-270.

Mukai H., Yokouchi Y. and Suzuki M. 1995. Seasonal variation of methane sulfonate in the atmosphere over the OKI islands in the sea of Japan. Atmos. Environ. 29, 1637-1648.

OECD, 1977. The OECD programme on long-range transport of air pollutants: summary report. OECD, Paris.

Pierson, W. R., Hammerle, R. H. and Brachaczek, W. W. 1976. Sulfate formed by interaction of sulfur dioxide with filters and aerosol deposit. Anal. Chem. 48, 1808-1811.

Putaud, J. P., Mihalopoulos, N., Nguyen, B. C., Campin, J. M. and Belviso, S. 1992. Seasonal variations of atmospheric sulfur dioxide and dimethylsulfide concentrations at Amsterdam island in the Southern Indian Ocean. J. Atmos. Chem. 11, 117-131.

Ramonet, M., Le Roulley, J. C., Bousquet, P. and Monfray, P. 1996. Radon-222 measurements during the TROPOZ II campaign and comparison with a global atmospheric transport model. J. Atmos. Chem. 23, 107-136.

Saltzman, E. S., Savoie, D. L., Prospero, J. M. and Zika, R. G. 1986. Methanesulfonate and non-sea-salt sulfate in Pacific air: regional and seasonal variations, J. Atmos. Chem. 4, 227-240.

Seinfeld, J. 1992. Atmospheric chemistry and physics of air pollution J. Wiley (eds.). $738 \mathrm{p}$.

Sicre, M. A., Marty, J. C. and Saliot, A. 1990. n-alkanes, fatty acid esters and fatty acid salts in size fractionated aerosols collected over the Mediterranean Sea. J. Geophys. Res. 95, 3649-3657.

Simo, R., Colom-Altes, M., Grimalt, J. O. and Albaiges, J. 1991. Background levels of atmospheric hydrocarbons, sulphate and nitrate over the Western Mediterranean. Atmos. Environ. 25, 1463-1471.

Spicer, C. W., Howes, J. E.Jr., Bishop, T. A. and Arnold, L. H. 1982. Nitric acid measurement methods: an intercomparison. Atmos. Environ. 29, 1487-1500.

Stephanou, E. G. 1992. Biogenic and anthropogenic organic compounds in eolian particulates in the East Mediterranean region-I. Occurrence and origin. Atmos. Environ. 26, 2821-2829.

Tsitouridou, R. and Samara, C. 1993. First results of acidic and alkaline constituents determination in air particulates of Thessaloniki, Greece. Atmos. Environ. 27, 313-319.

Wall, S. M., John, W. and Ondo, J. L. 1988. Measurement aerosol size distribution for nitrate and major ionic species. Atmos. Environ, 22, 1649-1656.

Warneck, P. 1988. Chemistry of the Natural atmosphere, Academic press, San Diego, California.

Yoshizumi, K. and Hoshi, A. 1985. Size distribution of ammonium nitrate and sodium nitrate in atmospheric aerosols. Environ. Sci. Technol. 19, 258-261. 